\title{
A representação das associações profissionais e os primeiros passos da Justiça Eleitoral (1932-1935)
}

The representation of professional associations and the first steps of Electoral Justice (1932-1935)

O artigo versa sobre a representação das associações profissionais ${ }^{1}$, entendida como a participação nos órgãos legislativos de deputados eleitos por essas instituições que tinham iguais poderes e atuaram ao lado da representação política tradicional, escolhida pelo conjunto dos cidadãos. No Brasil, a experiência foi adotada na Assembleia Constituinte de 1933-1934 e nos parlamentos nacional e estaduais de 1935 a 1937. O texto discute peculiaridades do processo de implantação e de regulamentação dessa medida na Constituinte e analisa a relação dela com os momentos iniciais do modelo de governança eleitoral que o Brasil adotara naquele período. Desse modo, pretende contribuir para o desenvolvimento de um conhecimento mais preciso no que tange à conjuntura de implantação da Justiça Eleitoral, a mais importante inovação realizada nesse campo.

O ponto de partida é um detalhe da história político-eleitoral do Brasil que tem passado despercebido pelos comentadores ou não tem sido destacado com a ênfase necessária: a Justiça Eleitoral, criada em 1932 em pleno Governo Provisório, o período de exceção instalado por Getúlio Vargas após chegar ao poder em 1930, passou a ter sob sua responsabilidade o total dos processos eleitorais do país e consequentemente a ser aquela que conhece-

\footnotetext{
É docente da Universidade Federal de Pelotas (UFPel). E-mail: albarret.sul@terra.com.br.

1 Ela recebeu diversas denominações enquanto estava sendo discutida nos anos 1930, mas também nas análises posteriores. Um desses termos, "representação classista”, será utilizado no artigo, especialmente para identificar o modelo adotado na Constituinte. O desenvolvimento do texto explicita as razões para tal escolha.
} 
mos hoje somente depois da promulgação da Constituição de 1934. Entre a sua criação e a reconstitucionalização (1932-1934), houve um período de hibridismo no modelo de governança eleitoral: a Justiça Eleitoral administrou o pleito e teve responsabilidade sobre o contencioso que definiu os 214 representantes do povo responsáveis pela redação da Constituição de 1934; no entanto, a esses constituintes se somavam quarenta representantes classistas, sendo que a participação da Justiça Eleitoral nesse processo ficou restrita ao contencioso, pois a realização foi uma atribuição do próprio Governo Provisório.

O desafio é explicar a partir de quais circunstâncias, com vistas a atender quais interesses, tal governança eleitoral híbrida acabou por ser adotada no país naquele período. Como o artigo pretende narrar e analisar, a resposta não é simples, pois envolve as conjunturas e os objetivos por trás da introdução da representação das associações profissionais, os valores políticos nela envolvidos, assim como as incertezas e as instabilidades políticas que caracterizaram o período pós-Revolução de 1930.

Para o desenvolvimento dessa tarefa, o artigo se debruça sobre manifestos, entrevistas, matérias jornalísticas e documentos da época, bem como sobre a Constituição de 1934 e os diplomas legais que regulamentavam a implantação da representação das associações profissionais na Constituinte, caso do Código Eleitoral e da série de decretos do Governo Provisório. Aborda, ainda, a ação da Justiça Eleitoral, mais especificamente de seu órgão de cúpula, o Tribunal Superior de Justiça Eleitoral (STJE) - hoje Tribunal Superior Eleitoral (TSE) - na resolução do contencioso oriundo de tal processo. As fontes secundárias são as investigações e as interpretações produzidas por cientistas políticos, historiadores e juristas que analisaram o tema.

$\mathrm{O}$ artigo está estruturado em quatro seções. A primeira opera como a introdução às demais: apresenta as circunstâncias gerais e o problema que guia o texto, assim como tipifica o modelo de governança eleitoral introduzido no período. A segunda discute a polêmica em torno da adoção da representação das associações profissionais na Constituinte e do modo como ela seria organizada, o que redundou na não participação da Justiça Eleitoral na gestão do processo eleitoral que definiu estes representantes. A análise das razões dessa decisão e do modo como foi conduzida a escolha dos deputados classistas é o foco da terceira. A seção derradeira aborda a ação da Justiça Eleitoral como responsável pelo contencioso alusivo a tal processo. 


\section{O Governo Provisório no rule making eleitoral}

O ponto inicial a ponderar é que, desde que chegou ao poder por meio de um golpe de Estado, Getúlio Vargas assumiu o compromisso de estabelecer uma nova Constituição na qual estariam plasmados os alicerces de uma profunda transformação do país. Embora sem uma delimitação temporal prévia para concluir tal tarefa, a transitoriedade do período fica patente na denominação adotada pelo novo governo, "Provisório", ou seja, aquele responsável pela condução da antiga para a nova e modificada ordem nacional.

No campo das regras institucionais, o primeiro passo efetivo para o cumprimento desse compromisso e a reconstitucionalização do país foi dado por meio do Código Eleitoral, promulgado como o Decreto n. 21.076, de 24 de fevereiro de $1932^{2}$. No que tange ao foco deste artigo, interessa especialmente o modelo de governança eleitoral que ele trazia. Esta é conceituada como "um grande número de atividades que cria e mantém o vasto arcabouço institucional no qual se realizam o voto e a competição política" (Mozaffar e Schedler, 2002, p. 7) e compreende três diferentes níveis: a) formulação das regras (rule making); b) aplicação das regras (rule application); c) resolução dos conflitos (rule adjudication). Embora discerníveis no plano analítico, é o conjunto desses níveis que promove a qualificação da governança, pois os riscos e as ameaças às eleições perpassam por todos eles (Mozaffar e Schedler, 2002, p. 7).

O rule making seria a escolha e a definição das regras básicas do jogo eleitoral. Nesse nível [...] são determinados, por exemplo, a fórmula eleitoral, os distritos eleitorais, a magnitude das eleições, as datas em que serão realizadas e outras questões legais que permitam aos concorrentes a segurança de como o jogo será jogado. Aqui também são definidas algumas regras que pouca atenção recebem da literatura política, como as regras da (in)elegibilidade e da organização dos órgãos responsáveis pela administração das eleições (Marchetti, 2008, p. 867).

No período em análise tal papel estava reservado ao Governo Provisório, que o realizou por meio de decretos com força de lei.

2 Além de criar a Justiça Eleitoral com as peculiaridades a serem destacas na sequência, o Código substituiu o sistema majoritário utilizado desde o Império por uma fórmula mista com predominância de características proporcionais, ampliou o direito de voto às mulheres e estabeleceu o voto secreto. 
O rule application envolve a "implementação e o gerenciamento do jogo eleitoral" (Marchetti, 2008, p. 867). Três são os desafios nesse âmbito: obter eficiência administrativa para empreender a contento a difícil e complexa tarefa de promover um pleito; apresentar neutralidade política; e promover prestação de contas das decisões (Mozaffar e Schedler, 2002, p. 8-10). O rule adjucation, por sua vez, envolve a solução dos litígios entre os competidores e ocorre antes, durante e depois da votação, visto que eles podem surgir em qualquer dessas etapas. Assim, o fato de o rule adjudication implicar a palavra final sobre a validade de um processo eleitoral não significa que ele só se desenvolva após o término dos momentos anteriores.

Marchetti (2008) explica que os três níveis da governança eleitoral geralmente não estão concentrados em um único órgão. As regras são quase sempre definidas no texto constitucional e em legislação infraconstitucional, enquanto a aplicação das regras e a adjudicação são de responsabilidade do electoral management board (EMB) ou organismo eleitoral (OE), como ele prefere denominar.

No que tange ao OE, a grande inovação surgida após a Revolução de 1930 - e mantida como tal até os dias de hoje - foi a criação da Justiça Eleitoral, concebida como uma única instituição responsável por conduzir as eleições e exercer tanto o rule application quanto o rule adjudication ${ }^{3}$. Além de cuidar do contencioso eleitoral, da verificação da regularidade do pleito, da homologação dos resultados e da diplomação dos eleitos - funções que são suscitadas pela denominação "Justiça Eleitoral" -, ele tem a responsabilidade de administrar o pleito, ou seja, prepará-lo, organizá-lo e executá-lo, o que inclui, por exemplo, credenciar eleitores, candidatos e apurar os votos.

Até então essas tarefas eram realizadas por instituições distintas. A verificação da regularidade vinha sendo promovida pelo parlamento, seguindo a tradição da chamada "revisão" ou "verificação dos poderes". Já a responsabilidade pela realização das eleições era prerrogativa quase exclusiva dos governos, que não contavam com um órgão específico e especializado para o desenvolvimento dessa atividade, a qual cabia aos municípios. A participação do Judiciário, quando ocorria, ficava circunscrita à organização da lista dos votantes e à presidência das mesas apuradoras.

3 Por meio de resoluções e da resposta a consultas, a Justiça Eleitoral tem a prerrogativa de complementar ou de esclarecer a norma legal (o chamado "poder normativo"), o que corresponde, em alguma medida, ao exercício do rule making. 
A opção consagrada no Código Eleitoral de 1932 foi atribuir o OE ao Judiciário. Esta é a segunda peculiaridade institucional do modelo de governança eleitoral brasileiro. Por trás dessa decisão reside a confiança em que o Judiciário seja detentor da imparcialidade e da autonomia imprescindíveis para a realização qualificada da governança eleitoral e a consequente preservação do interesse público por meio de eleições livres e verdadeiras. Consolidou-se a percepção de que "somente uma estrutura judiciária imparcial, de caráter permanente e com eficiência operativa, acrescida da igualdade do acesso de todos no processo eleitoral e da legitimidade de qualquer dos interessados em promover as medidas em defesa das diversas fases do processo eleitoral poderiam assegurar eleições idôneas" (Pinto, 2008, p. 87).

A outra face dessa decisão indica que ela implicou consciente e deliberadamente retirar dos governos e dos partidos a organização e a execução do processo eleitoral (Marchetti, 2008, p. 880) e, ao mesmo tempo, reconhecer a impossibilidade de dirimirem com padrões igualitários as controvérsias nas quais eram os principais interessados. De modo semelhante, Guerzoni Filho (2004, p. 43) exalta que a implantação do sistema eleitoral democrático no Brasil decorreu da desconfiança em relação ao sistema político-partidário.

Obviamente, a criação da Justiça Eleitoral não garantiu, como por milagre ou mágica, que os casos de fraudes tenham sido solucionados e que "representação e justiça" - o lema que inspirou a Revolução de 1930 e impulsionou o advento da tal inovação - tenham se instaurado de pronto. Todavia, é amplamente reconhecido, inclusive pelos seus contemporâneos, que, a partir do advento da Justiça Eleitoral, a qualidade do processo eleitoral aumentou e a falsificação das vontades sofreu forte inflexão ${ }^{4}$. O juízo de Leal (1975, p. 241), um crítico do sistema político brasileiro, é um bom atestado desses avanços: "de todas as eleições havidas até então foram as de maio de 1933 [as primeiras na vigência da Justiça Eleitoral] as mais regulares quanto ao mecanismo de alistamento, da votação e apuração do reconhecimento".

O sucesso alcançado por esse modelo de OE adotado no Brasil foi tão grande e persistente no tempo que os estudos têm se centrado na apresentação dos princípios nos quais ele está assentado e menosprezado a problemati-

4 Sobre a atuação da Justiça Eleitoral na eleição de estreia, em 1933, Cadah (2012, p. 54) comenta que "todos os estados tiveram votos, seções anuladas pelos TREs e, posteriormente, o TSE [então TSJE] ainda modificou resultados. Houve mudança de posição de candidatos, alteração de resultados e renovação de eleições em três estados - Mato Grosso, Espírito Santo e Santa Catarina". 
zação de algumas peculiaridades e circunstâncias do período em que foi gestado e introduzido. Um desses esquecimentos diz respeito ao papel que ele desempenhou na escolha da representação das associações profissionais na Constituinte. Tal lacuna pode decorrer da perda dos detalhes históricos, cada vez mais distantes e menos significativos à medida que o $\mathrm{OE}$ se consolidou. Igualmente, pode ser decorrência de suposições mais densas: a eleição classista era um indício da manutenção das fraudes eleitorais até então muito comuns no Brasil; logo, se ela fosse incluída na análise, lançaria dúvidas sobre o modo otimista como têm sido interpretados os primeiros passos do modelo de $\mathrm{OE}$ adotado no país e, como tal, deve ser mantida nas sombras.

Não concordamos com essa visão, e tampouco com o simples esquecimento do episódio, seja porque consideramos que os detalhes históricos devam ser resgatados, pois ajudam a lançar novas luzes sobre interpretações já consolidadas, seja porque entendemos que a não participação da Justiça Eleitoral na escolha dos deputados classistas na Constituinte não desvaloriza o modelo de governança eleitoral adotado no país desde 1932. Tal fato, porém, inclui-o em um processo contraditório, contingente e politicamente interessado, mais do que movido unicamente por ideais de implantação da verdade eleitoral. $\mathrm{Na}$ realidade, os interesses a motivar a adoção da representação das associações profissionais e a não incluí-la entre as atividades da Justiça Eleitoral são muito mais amplos e complexos, como se pretende abordar na sequência.

\section{A decisão sobre a representação das associações profissionais}

O Governo Provisório tinha autonomia para definir o novo ordenamento jurídico, uma vez que fechara todos os órgãos parlamentares do país, assumira os poderes Executivo e Legislativo e suspendera a Constituição de 1891. Nesse escopo figura a condição de estabelecer as regras que disciplinariam a redação da nova Constituição, que deveria consagrar a superação da República Velha e garantir o retorno à normalidade institucional. Assim, no caso das mudanças trazidas pelo Código Eleitoral de 1932, a possibilidade de incluir a representação das associações profissionais na Constituinte era um desses recursos estratégicos capazes de garantir a preservação dos interesses dos novos governantes ${ }^{5}$.

5 Dentre outros interesses que o Governo Provisório poderia mobilizar (e o fez), figuram: definir as regras do pleito de representação popular (decretos 21.076, de 24 de fevereiro de 1932, e 22.627, de 7 de abril de 1933); determinar o período das eleições (Decreto n. 21.402, de 14 de maio de 1932); definir as 
Contudo, a adoção da medida e a determinação do modo como ela seria organizada devia contemplar dois requisitos: a) ter apoio no próprio governo, o que implicava vencer resistências de grupos internos sem que isso colocasse em risco a coalizão que o sustentava; b) redundar em dividendos políticos efetivos, o que, naquela circunstância, significava ampliar e consolidar a base de apoio na futura Constituinte, mas também o modelo de organização sindical que vinha sendo implantado (unicidade sindical, com oficialização das entidades). Nesse contexto é que se podem entender: as dificuldades de efetivação dessa medida; as peculiaridades do formato institucional que ela assumiu e do processo eleitoral que selecionou esses representantes; assim como a relação que acabou por se estabelecer entre ela e o novo modelo de OE criado pelo próprio Governo Provisório.

Uma questão relevante é o fato de a representação das associações profissionais estar em flagrante contradição com os princípios que moviam o Código Eleitoral de 1932. Este foi construído em torno de um ideário liberal, no qual a existência daquela representação não fazia sentido, razão porque não figura na versão original do documento produzida pela equipe encarregada de sua formulação, a "subcomissão de reforma da lei e processos eleitorais". Sempre e quando fala da governança eleitoral (nunca com esses termos, bem entendido), o Código segue o princípio de que esta vai organizar, disciplinar e qualificar a representação do povo por meio de autoridades políticas individuais, eleitas por preferencialmente por partidos.

Dos três membros da subcomissão que redigiu o Código, dois se manifestaram claramente contrários à medida, que havia sido apontada genericamente por Vargas como um dos objetivos da "revolução" em manifestação pública, realizada em janeiro de 1931 (Vargas, 1938, v. 1, p. 81). Mário Pinto Serva, embora não tenha participado intensamente das reuniões por estar adoentado, criticara a ideia em livro lançado durante a elaboração do documento (Serva, 1931). Assis Brasil ponderou na edição revista e ampliada de Democracia representativa (1931) que o sistema a ser adotado por meio do Código Eleitoral, por dar espaço às forças políticas minoritárias, era suficiente para atender aos interesses das classes, logo tornava desnecessária a medida, 
a qual implicava atribuir um segundo voto aos membros dessas entidades. $\mathrm{O}$ terceiro componente, Rocha Cabral, publicou um livro em 1932 em que relatou detalhadamente o processo de feitura da legislação eleitoral e comentou cada um dos artigos (Cabral, 2004). A falta de uma referência substantiva ao tema revela muito mais do que se ele tivesse escrito algo acerca do assunto.

Desse modo, a representação das associações profissionais não pertencia ao horizonte de versão original do Código Eleitoral e, por extensão, da Justiça Eleitoral. No entanto, ela acabou por figurar no texto definitivo como parte de um único artigo, o 142, inserido já no final do documento, em uma seção que poderia ser chamada de "disposições transitórias" (Barreto, 2002). Conforme o texto, "no decreto em que convocar os eleitores para a eleição de representantes à Constituinte, o Governo determinará o número de representantes nacionais que a cada estado cabia eleger, bem como o modo e as condições de representação das associações profissionais" (Brasil, 1932, grifo nosso).

Para usar a linguagem relativa aos modelos de governança eleitoral: o artigo 142 atribuiu ao Governo Provisório o poder de exercer o rule making nesse tema. Igualmente, correspondeu àquilo que Mozaffar e Schedler (2002) chamam de "metajogo", ou seja, a norma prévia que fixa quem tem a prerrogativa de determinar as regras eleitorais. $\mathrm{Na}$ verdade, e como não poderia deixar de ser em tempos de ditadura e tratando-se de uma novidade institucional sem precedentes no país, a prerrogativa atribuída ao Governo Provisório era ainda mais ampla: ele podia definir a existência do próprio jogo da representação das associações profissionais.

A determinação contida no artigo 142 foi introduzida quando o anteprojeto formulado pela subcomissão chegou às mãos de Vargas. Os "tenentes"

6 Originários das rebeliões dos anos 1920, os "tenentes" (ou o tenentismo) acordaram com a Aliança Liberal, a dissidência oligárquica com a qual Vargas concorreu a presidente em 1930, e com ela realizaram a Revolução de 1930 e passaram a exercer atividades político-administrativas formais, como dirigir ministérios e interventorias estaduais. Apesar do nome e da origem, não eram unicamente ligados à instituição militar, pois havia os chamados "tenentes civis". A historiografia costuma afiançar que tiveram muita influência nos primeiros anos do período varguista, tendo perdido espaço após a revolução de 1932 e, principalmente, a partir da promulgação da Constituição de 1934 (Silva, 1966, 1967, 1968; Drummond, 1986; Forjaz, 1988; Borges, 1992; Moraes, 1994; Araujo, 1998; Prestes, 1999). Os "tenentes" eram contrários à imediata reconstitucionalização do país, pois estavam dispostos a promover uma profunda reforma do Estado, de forte conteúdo antioligárquico, e, em razão disso, exigiam a manutenção por longo tempo do período ditatorial. Porém, padeceram de imensas dificuldades para transformar a"energia revolucionária" que sempre propugnaram em um programa político coeso e em adotar estratégias comuns de luta, tornando-se, assim, mais uma marca do que um conjunto coerente de ideias. 
alegam terem sido os responsáveis pelo enxerto (Amaral Peixoto, 1975, p. 104-5; Marinho, 1935, p. 330). Ainda que tenham redigido tal artigo, não tiveram a autonomia para disciplinar a "representação das associações profissionais" como desejavam e/ou simplesmente não sabiam a forma como eles próprios pretendiam que ela participasse da futura Constituinte $^{7}$, pois o texto, apesar de garantir de algum modo essa participação - e todos os indícios apontam que deveria ser com os mesmos poderes da representação tradicional -, deixava até mesmo essa questão em aberto, sem trazer muitos elementos capazes de evidenciar como ela seria implantada.

Contudo, a incerteza não era privilégio dos “tenentes”. Os indícios (e a decisão final) apontam para o interesse da cúpula do Governo Provisório em fazer dos representantes das associações profissionais deputados constituintes como quaisquer outros, seja porque acreditava nos princípios que a sustentavam, seja por conveniência política de curto prazo. Porém, não havia convicção em torno da quantidade de cadeiras que eles ocupariam, do modo como se tornariam representantes e de como essas associações seriam reunidas para efeito de representação (constituency), tampouco do quanto estava disposto a pagar para implantar a medida. No bojo de tais incertezas, cuja superação estava condicionada às contingências políticas, figurava o papel que a Justiça Eleitoral ocuparia.

O primeiro movimento concreto do Governo Provisório nesse campo foi realizado somente em 26 de janeiro de 1933, quase um ano após a decretação do Código Eleitoral, quando o Ministério da Justiça enviou para consulta ao TSJE uma proposta de regulamentação da participação da representa-

7 As movimentações posteriores dos "tenentes", especialmente por meio do Clube Três de Outubro, entidade que pretendia unificá-los e liderá-los, indicam tal situação. Implantar essa representação figura como um dos objetivos no estatuto da entidade, de fevereiro de 1932, bem como um plano ambicioso para a reorganização política e social do país, que havia sido proposto no mesmo período e que foi aprovado na Convenção Nacional, em julho de 1932. Embora não trate especificamente da Constituinte, o plano advogava que tal representação constituísse uma das duas câmaras do legislativo nacional. O Clube voltou ao assunto em outubro de 1932, com a apresentação do "anteprojeto de sindicalização e representação das classes", mais uma vez destinado a regulamentar a futura ordem constitucional, e não a Constituinte, no qual era propugnado que a representação parlamentar das entidades fosse realizada por meio de "círculos de profissões afins", ressalvadas as diferenças entre classes. Já em novembro de 1932, ao versar especificamente sobre a Constituinte, defendeu que essa representação, organizada a partir desses círculos, tivesse o mesmo número de cadeiras que a popular (Barreto, 2001). Nenhuma dessas proposições foi integralmente atendida, seja pelo Governo Provisório, seja pela Constituinte. 
ção das associações profissionais na Constituinte ${ }^{8}$. Esta definia: a) poderes deliberativos; b) eleição indireta, a ser realizada pelas entidades em graus sucessivos (sindicato ou associação profissional, convenção estadual e, por fim, nacional), as quais seriam reunidas em seis categorias (agricultura, criação e atividades assemelhadas; indústria; comércio; transporte; educação e cultura; serviço público); c) um total de 24 cadeiras, pois cada categoria teria quatro deputados (dois de empregadores e dois de empregados, exceto a dos servidores públicos, na qual não há essa divisão); d) necessidade de a entidade ser reconhecida pelo Ministério do Trabalho, Indústria e Comércio (MTIC) para poder participar do processo. O documento ainda estabelecia que a realização do pleito seria de responsabilidade da Justiça Eleitoral, a exemplo do que ocorreria dentro de alguns meses no caso da representação popular (maio de 1933) ${ }^{9}$. As entidades interessadas em participar do processo de escolha dos representantes das associações profissionais deveriam se credenciar junto aos tribunais regionais eleitorais (TREs). O papel do governo (do MTIC, mais especificamente) seria o de enviar à Justiça Eleitoral a listagem daquelas efetivamente oficializadas (A Noite, 21 fev. 1933, p. 3).

Ao encaminhar o projeto à apreciação da Justiça Eleitoral, a intenção do ministro da Justiça, Antunes Maciel, era obter respaldo político, travestido de apoio legal à medida, e, assim, vencer as resistências que ela enfrentava, seja dentro do governo, notadamente de parte dos líderes civis mineiros e gaúchos, seja das forças oposicionistas. Estas desejavam a supressão da iniciativa ou que as associações profissionais exercessem função apenas consultiva ${ }^{10}$. Do ponto de vista jurídico, entretanto, esse respaldo era desnecessário, pois o Código Eleitoral autorizava o Governo Provisório a definir a questão ${ }^{11}$.

Ao se debruçar sobre o tema, o TSJE assumiu uma posição claramente política, visto que, em vez de eximir-se de manifestação, tendo o próprio

8 Gomes (1978) informa que essa proposta adapta à Constituinte o "anteprojeto de sindicalização e representação das classes" (nota 7), que havia sido encaminhado pelo Clube 3 de Outubro ao Governo Provisório.

9 Como parte da lenta preparação para a Constituinte, o período de realização dessa eleição havia sido fixado um ano antes, por meio do Decreto n. 21.402, de 14 de maio de 1932.

10 Essa alternativa era propugnada por várias forças políticas, caso da Chapa Única por São Paulo Unido, que a entendia como a medida correta para incorporar as associações profissionais ao Estado.

110 ministro tinha plena consciência desse fato. No ofício que acompanhou a proposta explicitou que "não seria possível ao governo tomar qualquer deliberação, a respeito de tão palpitante assunto, sem ouvir este egrégio Tribunal [...] [que] deverá estudar, portanto, o assunto sob integral liberdade, para opinar como melhor entender e apresentar emendas ou substitutivo ao esboço do projeto, formulado de modo a ficar o governo habilitado a decidir afinal" (Jornal do Commercio, 18 fev. 1933, p. 3). 
artigo 142 do Código Eleitoral como justificativa, preferiu opinar, não sobre a proposta encaminhada pelo Ministério da Justiça, mas sobre o princípio da representação das associações profissionais com poderes deliberativos. Assim, aprovou por unanimidade o relatório do ministro José Miranda Valverde, segundo o qual as entidades não deveriam participar com tais prerrogativas da Constituinte, mas como órgão consultivo (Jornal do Commercio, 1933, p. 3).

Conforme Gomes (1978, p. 59), a decisão do TSJE criou um verdadeiro impasse: com todos os caminhos percorridos, cabia agora ao Governo Provisório estipular a forma e o tipo dessa participação na Constituinte, sem a possibilidade de "dividir" esta responsabilidade. É relevante lembrar que, nesse momento, as eleições para a Constituinte ainda não haviam ocorrido e que sequer a distribuição de vagas entre os estados havia sido definida. Logo, Vargas não sabia o tamanho da base de apoio com a qual contaria na Constituinte nem o peso que a representação das associações profissionais poderia ter para garantir ou ampliar a condição majoritária. Criar essa bancada poderia reforçar essa base e precaver-se contra eventual fracasso nas eleições tradicionais, bem como poderia produzir afastamentos nas forças então tidas como fieis ao governo e enfraquecê-lo na Constituinte.

A decisão só foi tomada na reunião ministerial de $1^{\circ}$ de abril de 1933 , ocasião em que, por unanimidade, foi definida a participação das entidades profissionais na Constituinte com direito de voz e voto. Quatro dias depois, com o Decreto n. 22.621, ela foi oficializada. Este foi o primeiro documento legal que versou sobre o tema desde a promulgação do Código Eleitoral e, em obediência ao que preceituava o artigo 142, tratou da convocação da Constituinte $^{12}$. Ele determinou que, ao lado das 214 cadeiras da representação política, devidamente discriminadas por unidade da federação, existissem quarenta vagas para as "associações profissionais", definidas como os "sindicatos legalmente reconhecidos e [...] as associações de profissões liberais e as de funcionários públicos existentes nos termos da lei civil” (Brasil, 1933a, art. $3^{\circ}$ ). Ou seja, esses representantes teriam $15,7 \%$ das cadeiras e corresponderiam a aproximadamente $20 \%$ dos representantes políticos.

$12 \mathrm{Ou}$ melhor, definiu a composição da Constituinte, oficializou o Regimento Interno a ser adotado e determinou que esta seria convocada trinta dias após a comunicação oficial do TSJE do resultado da apuração das eleições dos representantes dos estados. A instalação ocorreu em 15 de novembro de 1933, o que foi estabelecido por meio do Decreto n. 23.102, de 19 de agosto de 1933. 
Qualquer dúvida que tivesse permanecido sobre a questão foi eliminada em um novo decreto, o n. 22.653, de 20 de abril de 1933, o qual dispõe que "tomarão parte na Assembleia Nacional Constituinte, com os mesmos direitos e regalias que competirem aos demais de seus membros, quarenta representantes de associações profissionais" (Brasil, 1933b). Esse mesmo decreto trouxe definições importantes no campo do rule making, como: a) adoção do modelo "classista", isto é, a divisão entre empregados e empregadores; b) definição de dois tipos de entidades a serem representadas (os sindicados legalmente reconhecidos conforme o Decreto n. 19.770, a "lei de sindicalização"13, e que, por isso, só poderiam existir como de empregadores e de empregados ${ }^{14}$; as associações profissionais, registradas como entidades de direito privado, nos termos da Lei Civil, e que abarcavam as de profissões liberais ${ }^{15}$ e as de funcionários públicos); c) distribuição paritária das vagas entre empregados e empregadores, isto é, a subdivisão das vinte correspondentes aos empregados entre os sindicatos da classe (18) e as associações de funcionários públicos (2) e das vinte alusivas aos empregadores entre os sindicatos da classe (17) e as associações de profissionais liberais (3), perfazendo, na prática, quatro grupos; e) determinação de processos eleitorais em datas distintas para cada um desses grupos; f) fixação do dia 20 de maio de 1933 como o prazo-limite para legalização da entidade a fim de que ela pudesse participar do pleito; g) estabelecimento de um delegado-eleitor por entidade apta, o qual necessariamente devia ser a ela filiado; h) exigência de que os eleitos tivessem exercício comprovado de dois anos da profissão, conforme a entidade a que estivessem vinculados; i)

13 Assim restava eliminada a possibilidade de entidades mistas, bem como a organização de categorias de profissionais liberais e de funcionários públicos sob a forma de sindicatos.

14 Essas denominações eram aquelas utilizadas na legislação relativa ao tema e evocavam o princípio de "harmonia de classes", ainda que o Decreto n. 19.770 também aplicasse os termos "patrão" (patronal) e "operário", tidos como ligados à "luta de classes". Aliás, esse decreto utiliza "empregado" e "operário" como duas modalidades de assalariado, correspondentes a quem realiza, respectivamente, trabalho intelectual e manual, mas somente com vistas a negar os efeitos jurídicos dessa distinção (Brasil, 1931). A definição legal de "empregador" foi tomada como evidente e, portanto, desnecessária, o que não foi seguido pela Consolidação das Leis do Trabalho (CLT) que o define como "a empresa, individual ou coletiva, que, assumindo os riscos da atividade econômica, admite, assalaria e dirige a prestação pessoal de serviço" (Brasil, 1943, art. 2).

15 Em nenhum documento legal o Governo explicitou a concepção de "profissões liberais". No anteprojeto do Ministério da Justiça rejeitado pelo TSJE foi esboçada uma definição aplicável a tal categoria, uma vez que o art. $8^{\circ} \S 1^{\circ}$ estabelecia que "serão considerados empregadores os que exercerem a profissão por conta própria sem subordinação a outrem, ainda que não tenham empregados" (A Noite, 1933). Pontes de Miranda (1936, t. 1, p. 269) afirma que o sentido então corrente da expressão é"toda profissão que não é cargo público, nem interior a alguma organização particular". 
definição de voto secreto para os delegados-eleitores; j) determinação do voto plurinominal não restrito e não cumulativo, ou seja, cada delegado-eleitor poderia escolher nomes correspondentes ao total de vagas do seu grupo ${ }^{16} ; \mathrm{k}$ ) aplicação da fórmula majoritária a partir de votos válidos ${ }^{17}$ (Brasil, 1933b).Na comparação com a proposta que o Ministério da Justiça havia encaminhado ao TSJE é possível verificar que alguns pontos foram mantidos, a indicar que compunham o alicerce do que pretendia o Governo Provisório: a) o caráter deliberativo dessa representação; b) a obrigatoriedade do reconhecimento das entidades junto ao MTIC para participar do processo eleitoral; c) a divisão entre empregadores e empregados. Todos os demais foram alterados - as categorias em que as entidades foram divididas, a quantidade de cadeiras a ocupar na Constituinte e o modo de seleção dos deputados - de forma a compor um modelo institucional próprio e bastante distinto de todos os que haviam sido sugeridos até então, seja pelos "tenentes", seja por intelectuais ou entidades (Barreto, 2001).

O Decreto n. 19.770 é unicamente classista, pois reconhece apenas empregados e empregadores, sem adotar subdivisões outras que não a de funcionários públicos (os empregados que possuem um patrão peculiar, o Estado) e a de profissionais liberais (os empregadores de si mesmos), sendo que estes até então não figuravam como categoria própria. Embora todos os modelos adotassem a divisão por classes (e a denominação fosse de uso corriqueiro na imprensa à época [A Noite, 21 fev. 1933; Jornal do Commercio, 18 fev. 1933]), nenhum dos modelos - especialmente os sugeridos pelos "tenentes" - se esgotava nessa distinção, pois exigiam a subdivisão por profissões ou por setor da atividade econômica. Da mesma forma, o Governo Provisório a inseriu em um único corpo, de formação mista (popular e classista), sem contemplar uma câmara exclusiva; deu-lhe um papel numericamente inferior ao da representação tradicional e, por conta das subdivisões, tornou cada grupo menor do que a representação dos grandes estados (Minas tinha 37 cadeiras e São Paulo, 22).

160 Decreto n. 22.696, o primeiro a versar especificamente sobre a representação das associações profissionais, ampliou o número de indicados, com vistas a incluir os suplentes (Brasil, 1933c).

$17 \mathrm{~A}$ explicitação de que era necessária a maioria absoluta dos votos válidos só figurou no Decreto n. 22.696. Assim, foi preciso disciplinar uma eventual segunda rodada de votação para suprir cadeira(s) de titular ou de suplente não preenchida(s). Concorreriam à vaga disponível os mais votados dentre os indicados não eleitos no limite do dobro de vagas a preencher, sendo exigida a maioria simples e, em caso de empate, sorteio (Brasil, 1933c). 
Os indícios apontam que o modelo adotado pelo Governo Provisório foi construído para garantir os princípios essenciais de ideia (e assim contemplar o interesse dos "tenentes" e dele próprio) sem, com isso, desagradar demasiadamente os aliados que eram contrários ou reticentes à medida. A exposição de motivos do ministro da Justiça, quando encaminhou a proposta a Vargas, explicita o "espírito" que o guiou: “[...] procurou-se, então, uma fórmula intermediária, harmonizadora, pela qual cumprindo o Governo os seus compromissos revolucionários, não perdesse a linha de discrição e cautela. [...] É uma fórmula, repito, de meio-termo, que deixará a desejar para os extremistas, porém significa uma leal satisfação do Governo, aos elementos esforçados que clamam pela representação de classes [...]" (apud Gomes, 1978 , p. 61 ${ }^{18}$. Em reforço a essa argumentação, existe a informação de que, ao fim de março, os interventores de Minas Gerais (Olegário Maciel), Rio Grande do Sul (Flores da Cunha), São Paulo (Waldomiro Lima) e Distrito Federal (Pedro Ernesto) firmaram um acordo em que aceitavam uma representação "moderada" das associações profissionais (Gomes, 1978, p. 61), a qual provavelmente correspondia ao arranjo institucional que descrevemos.

$\mathrm{Na}$ disputa entre os contrários à medida e os "tenentes", a vitória coube aos segundos, que viram a consagração da participação da representação das associações profissionais na Constituinte, a quebra do monopólio liberal-individualista de representação política e a afirmação do artigo 142, que haviam enxertado no Código Eleitoral ${ }^{19}$. Porém, a realização da Constituinte em si era uma derrota para eles, que não desejavam que o retorno à normalidade institucional ocorresse em estágio tão inicial da obra de transformação "revolucionária" do país, por saberem que continuavam fortes as bases sociais e econômicas de sustentação dos "inimigos", as forças oligárquicas.

Em outra perspectiva, se for pensado no interesse político mais do que nos modelos dessa representação, a vitória maior era do próprio do Governo

18Vargas (1938, v. 3, p. 33) admitiu tal dificuldade na mensagem que leu na sessão de instalação da Constituinte, em 15 de novembro de 1933, ao dizer que não fora fácil "assegurar a forma prática dessa inovação". Porém, ele reputou tal dificuldade não à costura política que ela envolveu, e sim à diversidade de alternativas encontradas no mundo. Ele não deixa de ter razão, pois havia grande polêmica e intenso debate intelectual, não apenas no Brasil, em torno de como entender essa representação e de que forma operacionalizá-la. Para mais detalhes, ver Barreto (2004). Sobre a questão na França, ver Parrot (1974) e Rosanvallon (1998).

19 Apesar disso, como previra o ministro Antunes Maciel na exposição de motivos citada anteriormente, a proposta "deixou a desejar aos extremistas", que sempre criticaram a fórmula do Governo Provisório e entendiam terem sido preteridos. 
Provisório. Afinal, era ele quem, teoricamente, garantia uma bancada favorável, seja para sustentar as "transformações sociais" já realizadas (muito aquém dos desejos difusos dos “tenentes”, mas que, sob qualquer perspectiva, exigiam mudanças radicais), seja para simplesmente consolidar-se no poder.

\section{Gestão da escolha dos representantes das associações profissionais}

O primeiro decreto do Governo Provisório a dedicar-se exclusivamente a regular a representação das associações profissionais, o n. 22.653, de 20 de abril de 1933, trouxe uma novidade importante no campo da governança eleitoral: ele determinou que a administração da escolha desses deputados (rule application) caberia ao Governo Provisório, mais especificamente ao MTIC. A Justiça Eleitoral, por meio do TSJE, atuaria como órgão de recurso e, portanto, seria responsável apenas pela resolução do contencioso eleitoral (rule adjudication). Nesse quesito o governo mudou de posição durante o longo e difícil processo decisório em torno da representação das associações profissionais na Constituinte. Na proposta formulada pelo Ministério da Justiça, a Justiça Eleitoral também seria o OE desse pleito, de modo a abarcar o conjunto das eleições do período.

Há vários aspectos a ponderar em tal decisão. Um deles é que o não envolvimento da Justiça Eleitoral poderia decorrer do posicionamento do TSJE contrário ao princípio da representação deliberativa das associações profissionais ao apreciar a proposta elaborada pelo Ministério da Justiça. Essa possibilidade não parece conter razão suficiente para explicar a decisão tomada, especialmente porque, se realmente quisesse que a Justiça Eleitoral participasse da administração desse processo, o Governo Provisório tinha os meios legais para determinar que isso ocorresse $\mathrm{e}^{20}$.

A interpretação mais encontrada destaca que a realização do pleito pelo Governo Provisório visava a atender o objetivo de os eleitos concordarem com o governo, formarem a base de apoio na Constituinte, razão pela qual a eleição foi permeada de fraudes (Henriques, 1966, p. 260-1; Connif, 1975,

20Também é possível supor que a imensa dificuldade para apurar os votos e aplicar a fórmula eleitoral que a Justiça Eleitoral enfrentou, somada à necessidade de julgar o contencioso (Cadah, 2012), tenha contribuído para a decisão do governo, de modo a evitar que esta ficasse demasiadamente sobrecarregada ao ter de organizar um segundo pleito. Contudo, essa hipótese não se sustenta, pois quando o governo definiu a questão (em abril de 1933) essas dificuldades não haviam se manifestado (a votação ocorreu em maio de 1933). 
p. 76; Moraes Filho, 1976, p. 18); Araújo, 1998, p. 253). Consequentemente, o afastamento da Justiça Eleitoral era uma forma de facilitar essas práticas, o que não seria possível (ou enfrentaria muitas dificuldades) se esta administrasse o processo.

Não há razão para negar que Vargas tivesse interesse na introdução dessa bancada na Constituinte. A demora em decidir a questão e o esforço de engenharia política contida na proposta enfim implantada são indícios do quanto ele valorizava a medida, bem como de quanto sua adoção esteve condicionada a não fraturar a base aliada. No entanto, é equivocado supor, a partir disso, que tal inovação institucional foi criada unicamente com esse objetivo, que toda a bancada seria governista e que para garantir tal resultado o Governo Provisório afastou a Justiça Eleitoral com vistas a ter o caminho livre para praticar as fraudes necessárias.

É preciso destacar: ainda que tudo corresse bem para o Governo Provisório na futura eleição para a representação tradicional e ele conquistasse (como ocorreu) uma robusta base de apoio, de modo a não tornar a existência da bancada classista tão necessária quanto supõe tal teoria, a adoção dessa representação continuaria a ser estratégica. Isso porque ela abrangia objetivos mais amplos, pelos quais, para que fossem contemplados, aceitava o risco de os classistas não apoiarem integralmente o Governo e a medida servir para forças opositoras como atalho de acesso à Constituinte, caminho que não era oferecido com as mesmas facilidades no pleito popular realizado segundo as normas do Código Eleitoral.

Nessa linha de argumentação, a exclusão da Justiça Eleitoral do rule application do pleito classista não visou à promoção facilitada de fraudes, sendo antes uma forma de distinguir ainda mais claramente que as duas representações constituíam modelos distintos e, por isso, cada uma seria gerida por um OE diferente. No espírito presente no Código Eleitoral, a nascente Justiça Eleitoral havia sido projetada e organizada para cuidar unicamente da representação tradicional. Coube ao governo, então, gerir a eleição da outra, uma inovação radical e claramente dissociada da representação popular.

Comecemos pela análise das supostas fraudes cometidas pelo Governo Provisório ao desempenhar o rule application nesse pleito, pois, por meio dele, podemos demonstrar o papel maior que cabia à representação das associações profissionais na ótica varguista. Afirmamos que as regras não foram manipuladas e os procedimentos passíveis de serem interpretados 
como fraude, se ocorreram, não pretendiam aumentar a bancada favorável ao governo, e sim garantir que houvesse a efetiva participação das associações profissionais, ainda que estas fossem oposicionistas.

Inexistiu fraude disseminada no pleito classista com vistas a inflar a bancada governista porque ela não era necessária, e não porque o Governo não se dispusesse a realizá-la. Nesse sentido, adotamos o entendimento apontado por Ricci e Zulini (2014) ao estudarem os pleitos da Primeira República: quando há o controle sobre a máquina administrativa do pleito não existe a necessidade de praticar fraudes, afinal, estas surgem quando se tornam o último recurso para controlar o voto e evitar que os adversários tenham sucesso. E este era o caso do Governo Provisório em relação às eleições classistas.

A maior parte dos representantes classistas eleitos e dos delegados-eleitores, notadamente aqueles vinculados à classe dos empregados, já havia aderido ao modelo de sindicalismo oficial ou organizado a categoria após o estímulo oriundo da chancela do Estado promulgado pelo Decreto n. 19.770, sendo igualmente favorável à legislação social-trabalhista que vinha sendo implantada. Por consequência, apoiaria o governo e lutaria para garantir a constitucionalização dessas medidas. O cuidado que o Governo Provisório precisava ter - e teve - era o de monitorar a seleção desses nomes para minimizar infiltrações, como a de opositores que oficializaram entidades de empregados e buscaram garantir, por meio da representação das associações profissionais, acesso à Constituinte ou ampliar o acesso que já haviam conquistado ${ }^{21}$; e a de aliados radicais, como setores dos "tenentes", pouco confiáveis e que poderiam dividir a base de apoio. No que tange aos empregadores (extensiva aos profissionais liberais), a expectativa do governo não era a de ter uma sólida maioria nessa bancada, ao contrário, supunha que ela atuaria em conformidade a outros interesses ${ }^{22}$.

21 Essa não era uma mera possibilidade, pois não apoiadores do governo conseguiram vaga na bancada dos empregados. Citam-se dois casos: a "minoria proletária", formada por quatro deputados, que defendeu posições mais radicais durante a Constituinte e, descontente com o resultado alcançado, recusou-se a assinar a versão final do texto constitucional; o líder comunista Alvaro Ventura, a ressalvar que este era suplente e ascendeu ao cargo após a promulgação da Constituição, quando os deputados constituintes assumiram as funções congressuais ordinárias.

22 De fato, quatro dos dezessete representantes dos empregadores e um dos três das profissões liberais reforçaram a bancada da Chapa Única por São Paulo Unido, a principal corrente de oposição a Vargas. A soma desses cinco deputados aos quatro da "minoria proletária" indica que, no mínimo, nove dos quarenta representantes classistas não estavam vinculados à base governista (22,5\%). 
Além disso, a eleição dos deputados classista ocorreria quase três meses após a definição dos 214 deputados populares. Nesse período, o governo já conheceria a correlação de forças da Constituinte, motivo pelo qual poderia calcular com mais propriedade quais objetivos específicos ele precisaria atingir com a bancada como um todo (e em cada um dos grupos) e quais fatores de risco estariam envolvidos no pleito $^{23}$.

Ocorre que essa representação não visava apenas a reforçar a base de apoio do Governo Provisório, mas a objetivos mais amplos, como já dissemos. A oportunidade de oferecer assento no processo Constituinte às associações profissionais era um importante reforço ao modelo de organização das categorias que o governo vinha implantando e que recebia forte resistência de setores da classe trabalhadora, especialmente anarquistas e comunistas, mas principalmente, e com ainda mais força, da classe patronal. Como a condição sine qua non para pleitear essa representação era o registro dos sindicatos junto ao MTIC, todos aqueles que quisessem ocupar tal espaço precisariam aderir, ao menos formalmente, ao modelo de organização oficial contido no Decreto n. 19.770. Há de se enfatizar que a perspectiva de participar com direito de voz e de voto do processo constituinte e assim defender diretamente seus interesses mobilizava intensamente os empregadores. Como consequência, eles não tiveram outra saída senão adequar-se à sindicalização oficial.

Para o governo, por sua vez, para efetivar a proposta de "harmonia de classes" que subsidiava tanto a representação das associações profissionais quanto a intervenção do Estado nas relações de trabalho, era imprescindível a adesão dos empregadores. A dos trabalhadores já vinha sendo obtida, seja por meio da conhecida e antiga repressão, seja porque estes aderiam ao sindicato oficial em razão da proteção à organização das categorias e ao fato de, com as medidas adotadas pelo governo, aparentemente terem ganhos maiores e mais imediatos do que os patrões.

23Conforme os cálculos de Silva (2012), entre a representação política tradicional, a bancada governista atingia $70,8 \%$ das cadeiras. Ainda que, em função do cancelamento do pleito ou de contestações na Justiça Eleitoral, nem todas as bancadas estaduais estivessem plenamente definidas ao final de julho, quando começaram as eleições classistas, o cenário já indicava a Vargas que ele era majoritário na futura Constituinte. Até mesmo o insucesso em São Paulo já estava devidamente contabilizado e principiavam as negociações com a Chapa Única, que elegera dezessete das 22 cadeiras (Gomes, 1980). Ressalva-se, ainda, que considerando a estimativa constante na nota anterior, Vargas era amplamente majoritário tanto na representação popular quando na classista, e não havia tanta distinção entre elas no índice de governismo (70,8\% e $77,5 \%$, respectivamente). 
Consciente da necessidade da participação dos patrões e interessado em que ela acontecesse - ainda que sua bancada pudesse engrossar a oposição -, o governo fez vistas grossas à estratégia montada pela classe: manter a organização de entidades civis e autônomas em relação ao Estado e, em paralelo, criar sindicatos conforme as exigências legais. Na mesma medida, por meio do Decreto n. 22.745, de 24 de maio de 1933, alterou as regras que havia originalmente fixado e ampliou o prazo de reconhecimento de sindicatos junto ao MTIC para que as entidades pudessem eleger seu delegado-eleitor. O dia 20 de maio passou a ser o limite para o ingresso do pedido no MTIC e o reconhecimento poderia ocorrer até o dia 15 de junho (Brasil, 1933d). Embora a medida tivesse como justificativa a dificuldade operacional do MTIC para atender a grande demanda por reconhecimentos e também permitisse a ampliação no número de sindicatos de empregados, o efeito foi muito maior junto aos empregadores: se o prazo não fosse modificado, apenas oito sindicatos patronais poderiam participar do processo e, no final, 83 delegados-eleitores acabaram homologados pelo MTIC (Barreto, 2001).

Autoestabelecido como gestor dessa eleição, o Governo Provisório adotou as medidas administrativas e organizacionais necessárias à realização do pleito. Em todas, exerceu poder equivalente ao que o Código Eleitoral atribuía à Justiça Eleitoral - e que a caracteriza e ainda hoje é utilizado -, qual seja, o de fixar normas uniformes para aplicação das leis e regulamentos eleitorais, além de expedir as instruções que entenda necessárias (Brasil, 1932, art. 14, 4), o que é realizado por meio de resoluções. No caso em questão, as resoluções surgiram sob a forma de decretos.

Dois conjuntos de exigências chamam a atenção e são essenciais para entender a estratégia que o Governo Provisório adotou para garantir uma bancada favorável e precaver-se contra “infiltrações”. É importante destacar mais uma vez: elas não implicaram ações fraudulentas ou manipulação das regras eleitorais, entendidas como procedimentos que impedissem a livre competição entre os pretendentes a deputado constituinte classista ou condicionassem previamente um determinado resultado eleitoral. Ao contrário, deixavam a disputa "em aberto" e, por isso, não eram neutros, visto que, dessa forma, garantiam o protagonismo do governo.

O primeiro conjunto não previa inscrição de candidaturas em qualquer etapa do processo eleitoral. Na prática, fixava que, ressalvadas as restrições legais de elegibilidade, os delegados-eleitores poderiam votar no nome que 
desejassem, inclusive em quem não estivesse presente ao evento ${ }^{24}$. As exigências para ser elegível à Constituinte como representante classista eram: a) nacionalidade brasileira; b) ser alfabetizado; c) estar na posse dos direitos civis e políticos; d) ter mais de 25 anos, sem distinção de sexo; e) exercer a respectiva profissão há mais de dois anos, comprovada por atestado, com firma reconhecida, fornecido por autoridade judiciária, policial ou pelo empregador; f) estar filiado à associação ou sindicato da categoria pela qual foi eleito (Brasil, 1933c). Provocava inelegibilidade o fato de pertencer à mesma organização sindical ou profissional de outro eleito. Ressalva-se que os primeiros três requisitos são comuns a todos os constituintes e os seguintes são específicos à condição de classista.

A “inflação" de candidatos potenciais, fruto da ausência da exigência de inscrição prévia, associada à regra da necessidade de obtenção de maioria absoluta dos votos válidos, dificultava sobremaneira que alguém conseguisse consolidar as chances de ser eleito diante das diversidades do meio, especialmente no caso dos empregados. Ao mesmo tempo, para viabilizar a eleição, obrigava esse pretendente (e as forças por trás dele) a realizar costuras políticas em sua entidade, em sua cidade ou em seu estado, em sua categoria profissional, assim como com o grupo ideológico ao qual estava mais próximo, com o(s) interventor(es) ou com o próprio Governo Provisório.

A dificuldade de definição de acordos eleitorais prévios entre as entidades e entre os eleitores era ampliada pelo fato de o pleito ser realizado em uma única convenção, na capital federal, o que eliminava as instâncias intermediárias (convenções regionais ou estaduais), as quais eram propugnadas na proposta do Ministério da Justiça e defendidas pelos “tenentes”. Em última instância, esse conjunto de peculiaridades criava um ambiente favorável a que o Governo Provisório comandasse as articulações ${ }^{25}$.

O segundo conjunto de regras era a exigência de os delegados-eleitores chegarem à capital federal pelo menos oito dias antes do pleito do grupo a

24A proposta do Ministério da Justiça repudiada pelo TSJE previa a inscrição de candidatos. A ausência de candidaturas prévias fez com que, dentre os eleitos dos grupos de empregadores, funcionários públicos e profissionais liberais, alguns não fossem delegados-eleitores. Ao contrário, no caso dos empregados, todos participaram da sessão de votação.

25 Gomes (1978) afirma que Luiz Aranha, chefe de gabinete do ministro da Justiça e irmão de Oswaldo Aranha, foi o principal articulador no governo. É interessante que alguém não vinculado ao MTIC tenha desempenhado tal papel, a indicar que talvez a administração do pleito coubesse ao MTIC e a gestão "política" ao Ministério da Justiça (ou, ao menos, a membros que atuavam nesse setor). 
que pertencesse, bem como a possibilidade de o ministro permitir, mediante solicitação, que eles fizessem reuniões preparatórias. Em contrapartida, durante a sessão de votação, os debates estavam expressamente proibidos. Sem contar os encontros não formais entre os eleitores, que poderiam ocorrer (e ocorreram) nesse intervalo de tempo, haveria amplas possibilidades de discussões entre os delegados-eleitores para articular interesses e votos, construir candidaturas e viabilizá-las com vistas à conquista da cadeira. Não surpreende, portanto, que o Decreto n. 22.940, o último a disciplinar o pleito, divulgado em 14 de julho de 1933, tenha explicitado que a cédula poderia ser impressa, datilografada ou mimeografada, ou seja, refletir os acordos produzidos nesses encontros. Na mesma medida, ele determinou que os suplentes não seriam os mais votados logo abaixo dos eleitos (como previa o Decreto n. 22.696), e sim que o eleitor deveria discriminar, no limite de nomes que pudesse indicar, os escolhidos para titular e para suplente (Brasil, 1933e). A novidade fazia com que, na prática, houvesse concorrências distintas para cada condição. Provavelmente, ela foi fixada porque, a partir de acordos políticos, alguns nomes deveriam ser eleitos suplentes, uma vez que seria muito difícil coordenar votos de modo a garantir esse resultado caso a norma anterior prevalecesse.

É nesse contexto que o Governo Provisório surge como único ator a conhecer a totalidade dos eleitores, a ter a condição privilegiada de atuar como o principal articulador político e maestro das negociações, portanto, com capacidade para coordenar os votos, viabilizar candidaturas de interesse dele ou, no mínimo, atuar com poder de veto sobre postulantes indesejáveis ou pouco confiáveis. Isso não significa dizer que ele teve a plena capacidade de impor candidatos, e sim que estava em significativa vantagem estratégica nas negociações inerentes a uma decisão desse tipo. Afinal, sempre há alguma margem de risco ou de incerteza em um pleito, mesmo tratando-se de um processo com as características de uma Constituinte, em que o Governo controlou a elaboração e a aplicação das normas (rule making e rule application). Se havia negociação, ele teria de ceder em alguma medida. Logo, abria-se espaço (mesmo que minoritário) a candidatos dispostos a não cerrar fileira integralmente na força de sustentação de Vargas, que procurassem ter uma atuação mais independente ou reivindicar e negociar alguns pontos que não faziam parte da perspectiva do governo ou não eram prioridade dele. Atenta-se, ainda, para o fato de que muitos eleitores podem não ter 
concordado com a relação de nomes definida na reunião prévia ou que o acordo não envolvia todas as vagas em disputa, sem contar a possibilidade de haver mais de uma chapa ou a ausência de qualquer consenso. E esses diferentes cenários se manifestaram no pleito de cada uma das categorias.

A indicar a existência e a força desses acordos firmados com a participação do Governo Provisório, 29 das quarenta cadeiras foram definidas já no primeiro escrutínio, ou seja, os candidatos obtiveram a maioria dos votos. No entanto, há diferenças significativas entre os grupos: no dos funcionários públicos, os dois eleitos foram escolhidos na primeira rodada, mas no dos profissionais liberais, nenhuma das três vagas foi resolvida na primeira votação ${ }^{26}$. No dos empregadores, houve acordo em torno de quinze das dezessete cadeiras, todavia, seguiu-se uma grande disputa em torno das duas restantes. Na votação dos empregados, dois terços das vagas foram resolvidos na primeira votação, porém foi preciso um segundo escrutínio para definir seis das dezoito cadeiras, em um processo que só foi concluído vinte horas após o início da sessão (Barreto, 2001).

Tendo atingido este ponto, é importante evidenciar que a estratégia adotada pelo Governo Provisório no âmbito da representação das associações profissionais foi diferente daquela aplicada no da representação popular, o que redundou, em relação à situação em análise, na não participação da Justiça Eleitoral no rule application do pleito classista. Apesar disso, tanto em um caso quanto no outro, os objetivos a serem atingidos eram os mesmos: fortalecer tanto a base de apoio na Constituinte quanto o projeto de centralização política e de estabelecimento de um encorpado Estado nacional como propulsor de significativas transformações sociais e econômicas.

Seguindo essa lógica, no caso da representação popular se tornou imprescindível incorporar uma série de inovações institucionais consubstanciadas por meio do Código Eleitoral de 1932, dentre as quais: substituir o sistema eleitoral majoritário por um misto, com características do modelo proporcional; ampliar o universo de eleitores potenciais, recadastrá-los e oferecer

26Dois elementos podem ter colaborado para a inexistência de um acordo prévio: a ausência de uma identidade comum às profissões liberais, pois cada uma se via como portadora de interesses específicos e que só poderiam ser contemplados por um representante pertencente à própria corporação; a divisão política entre os candidatos, pois os principais líderes da posição pró e contra a representação das associações profissionais pertenciam a esse grupo e se digladiaram durante a Constituinte (o engenheiro Ranulfo Pinheiro Lima, vinculado à Chapa Única; o médico Abelardo Marinho, ligado aos "tenentes"), de modo que cada uma pretendeu eleger o seu candidato. 
garantias ao exercício do voto; criar um OE imparcial e judicializado. Como argumenta Silva (2012), as novidades trazidas pelo Código Eleitoral não implicavam simplesmente o desejo da implantação da "verdade eleitoral", mas também tinham em vista atender aos interesses políticos de curto prazo do Governo Provisório. Assim, nos termos das inovações implantadas por Vargas, "representação e justiça" também significavam erodir os elementos nos quais os adversários tinham se sustentado como forças políticas predominantes ao longo da República Velha e novamente no pós-1930 caso as mudanças não fossem realizadas. Logo, as adoções da Justiça Eleitoral, do voto secreto e de um sistema eleitoral sensível às minorias correspondiam, igualmente, a um arranjo que enfraquecia as oligarquias por meio do investimento em disputas eleitorais competitivas, já que estas continuavam organizadas em torno de suas antigas máquinas partidárias. Em tais disputas havia chances reais para que as antigas forças oposicionistas estaduais, antes asfixiadas, ganhassem espaço e/ou surgissem novas forças políticas, normalmente segundo partidos articulados pelos interventores, eles próprios representantes das antigas oposições ou de uma nova classe política. Em ambos os casos, essas forças que foram viabilizadas pela "revolução" eram aliadas efetivas ou potenciais de Vargas, sendo imprescindíveis à sustentação e à continuidade dele no poder ${ }^{27}$.

Silva (2012) baseia o raciocínio a partir do "realismo político" de Vargas, mas a demonstração do argumento padece de uma omissão que não invalida o resultado a que chegou (e com o qual concordamos), embora o limite. Ele considera apenas a representação política tradicional e ignora o peso decisório da representação das associações profissionais na Constituinte (quarenta votos em 254). Contudo, esta fazia parte dos cálculos do Governo Provisório. Assim, o realismo político que sustenta o argumento é desenvolvido a partir da análise de um cenário parcial e, portanto, inexistente no contexto político da época.

Desse modo, pode-se argumentar que, com vistas a atingir os mesmos objetivos políticos de curto prazo e de viabilizar as mesmas transformações, o

27 Silva (2012) demonstra que as eleições tradicionais para a Constituinte de 1933, realizadas seguindo os princípios estabelecidos pelo Código Eleitoral de 1932, impactaram a configuração dos sistemas partidários estaduais e substituíram a regra vigente na República Velha, na qual raramente havia mais do que um partido na representação parlamentar, por modelos bipartidários (governo-oposição), decorrentes de eleições competitivas. A mesma tendência se repetiu nas eleições de 1934 para a Câmara Federal e as assembleias estaduais. 
Governo Provisório adotou também o modelo de representação classista. Em teoria, este seria independente das oligarquias, assim como uma alternativa para contemplar interesses e forças sociais que passaram a ser reconhecidas como válidas e estratégicas no pós-1930, mas que não eram plenamente satisfeitas pela modelo tradicional de composição dos órgãos parlamentares. Para tal caso não caberia nenhuma das inovações trazidas pelo Código Eleitoral, mas tampouco foi necessário servir-se do velho instrumento da fraude eleitoral para alcançar os objetivos pretendidos, a exemplo do registrado no âmbito da representação popular.

\section{A Justiça Eleitoral e o contencioso do pleito classista}

Por fim, é preciso lembrar que, como havia sido previsto nas normas definidas pelo Governo Provisório, o papel da Justiça Eleitoral foi o de solucionar o contencioso eleitoral (rule adjudication) ou de atuar, na prática, como organismo de verificação de poderes, em substituição ao papel que até então fora desempenhado pelo Legislativo.

As eleições para os quatro grupos sofreram algum tipo de contestação junto à Justiça Eleitoral, no entanto, houve menos demanda na eleição para os empregados e mais na dos empregadores. Esse quadro parece refletir a validade dos acordos firmados entre os primeiros, o grau de interesse e de disputa existente entre os segundos, bem como da mais forte disposição de recorrer à Justiça diante de alguma inconformidade em relação ao pleito. Novamente, a dinâmica da eleição classista parece respaldar os achados de Ricci e Zulini (2014): as contestações aos resultados eleitorais, as acusações de fraude ou de descumprimento das regras são mais intensas quando há menos controle da máquina administrativa e maior disputa entre os competidores. Assim, como o Governo Provisório preocupou-se mais intensamente com a eleição dos empregados e deu mais autonomia aos empregadores para que forjassem as negociações, houve mais recursos à Justiça Eleitoral nesta categoria.

Em contrapartida, o TSJE alterou o resultado somente no caso dos empregados. Ele cassou o diploma de um dos eleitos por ter menos de 25 anos e, desse modo, descumprir o artigo 18 do Decreto n. 22.696 ${ }^{28}$. A defesa do 
impugnado girou em torno da improcedência da distinção estabelecida pelo Governo Provisório entre os constituintes, pois o Código Eleitoral estabelecia 21 anos como idade mínima para exercer o cargo. O TSJE manifestou estranheza com tal distinção e afirmou desconhecer razão que a justificasse, porém, reconheceu que, com a suspensão da ordem constitucional, o Governo Provisório tinha plena capacidade para fixar as normas que achasse necessárias com vistas à realização da Constituinte. Desse modo, manteve a cassação (TSJE, 1933a, 1933c).

O TSJE também se defrontou com recursos eleitorais contra seis deputados da categoria dos empregadores. Em todos os casos, a mesma alegação: os eleitos não haviam comprovado dois anos de exercício efetivo da condição de empregadores. O órgão de cúpula solicitou esclarecimentos ao MTIC, e este se isentou de responsabilidade ao responder que, como nem todos os eleitos eram delegados-eleitores, não era possível analisar a documentação e confirmar a plena elegibilidade deles, responsabilidade que caberia à própria Justiça Eleitoral, como estava ocorrendo a partir das contestações. De fato, o TSJE acabou por desempenhar esse papel ao solicitar aos réus os documentos que comprovassem o tempo de exercício da atividade e que dirimissem a dúvida suscitada nos recursos. Os seis eleitos apresentaram documentação considerada válida pela Justiça Eleitoral e tiveram o diploma confirmado (TSJE, 1933d).

Houve, ainda, um recurso não contra algum eleito, mas contra o próprio processo eleitoral. Ele teve origem no grupo dos funcionários públicos, sob a alegação de descumprimento das regras por parte do MTIC, tanto pela publicação fora do prazo da lista de entidades aptas a indicar delegado-eleitor como pelo aumento no número de suplentes. Nos dois casos, como parte do processo de julgamento, o MTIC teve de fornecer explicações à Justiça Eleitoral. Sobre o primeiro, alegou zelo na verificação dos dados e dificuldades operacionais para desempenhar tal função. Quanto ao segundo, afirmou que a decisão tomada pelo Ministro do Trabalho correspondia à prerrogativa de dirimir questões, prevista na própria legislação ${ }^{29}$. O TSJE acolheu as alegações oficiais e manteve a validade do pleito (TSJE, 1933b).

pelo eleito; 2) a falha do MTIC para verificar o cumprimento das regras; 3) o interesse do Governo em permitir tal descumprimento, pois a eleição dele fazia parte dos acordos estabelecidos entre os delegados-eleitores (Barreto, 2001).

290 Decreto n. 22.696 autorizou o ministro a resolver questões de ordem, surgidas durante a sessão de votação (Brasil, 1933c, art. 14). 
Outro recurso foi interposto contra um dos eleitos do grupo dos profissionais liberais. O recorrente alegou uma série de impropriedades: delegados-eleitores não poderiam ter sido homologados por problemas no registro da entidade ou no dos participantes da assembleia geral que os indicou; um dos eleitos não cumpria os requisitos legais de dois anos de exercício da atividade. A decisão da Justiça Eleitoral indicou de que essas questões não lhe diziam respeito, e sim ao MTIC, a quem a reclamação deveria ter sido encaminhada (TSJE, 1933e).

O caminho seguido pelo STJE, portanto, foi o de reconhecer a autonomia do Governo Provisório não só no rule making (como expressou ao se pronunciar no recurso do representante dos empregados cassado), mas também em todas as decisões relativas ao rule application, o controle sobre o processo eleitoral de cunho administrativo (validação de entidades e de delegados-eleitores). Logo, obediente ao papel que lhe era institucionalmente reservado, a Justiça Eleitoral só se manifestaria sobre alegações relativas ao descumprimento "objetivo" de normas legais por parte dos candidatos (idade mínima, tempo de exercício da profissão), isto é, o rule adjudication.

Essa ordem de coisas mudou após a promulgação da Constituição de 1934. De um lado, a representação das associações profissionais foi consagrada como parte da Câmara dos Deputados ao lado da representação política tradicional, a exemplo do que ocorrera na Constituinte (artigo 23$)^{30}$. De outro, a Justiça Eleitoral também foi constitucionalizada e oartigo 83 exarou que ela teria "competência privativa para o processo das eleições federais, estaduais e municipais, inclusive as dos representantes das profissões" (Brasil, 1934). Desse modo, foi a partir de 1934 que a Justiça Eleitoral assumiu, efetivamente, o rule application e o rule adjudication da totalidade dos representantes de caráter eletivo, tendo coordenado os processos eleitorais para a primeira legislatura da Câmara dos Deputados, das diferentes assembleias estaduais e do Distrito Federal.

A ruptura trazida pelo Estado Novo, em 1937, fechou todos os órgãos legislativos do país, eliminou os processos eleitorais e, com eles, a Justiça Eleitoral. Esta seria retomada na reconstitucionalização de 1945, mas a representação das associações profissionais não a acompanhou, pois nunca mais foi experimentada no país e ficou "congelada" na história política como um curto e inusitado arranjo institucional dos anos 1930. 


\section{Conclusão}

O texto abordou a relação entre a Justiça Eleitoral e a representação das associações profissionais, aplicada no Brasil na Assembleia Nacional Constituinte de 1933-1934 e na legislatura da Câmara dos Deputados iniciada em 1935 e interrompida em 1937 pelo golpe do Estado Novo. Para contextualizar tal relação, abordou as circunstâncias políticas que redundaram na adoção de tal tipo de representação, analisou as peculiaridades do modelo institucional implantado e ponderou o fato de o próprio Governo Provisório ser responsável pela administração do processo de escolha desses constituintes.

Efetivamente, foi somente após a promulgação da Constituição de 1934 que a Justiça Eleitoral passou a ter sob sua responsabilidade o total dos processos eleitorais do país. Isso porque, no pleito para a Constituinte de 1933, os 254 membros foram selecionados em processos que tiveram tanto a Justiça Eleitoral quanto o próprio governo como OE, sendo que a verificação de poderes (rule adjudication) de todos eles coube à Justiça Eleitoral, ou seja, o modelo de governança eleitoral adotado naquele período ainda contemplava um hibridismo.

O mais interessante é que esse modelo vigorou apenas naquele momento e diverge de todos os outros utilizados no país antes e depois dele. Isso porque, no pré-1930, o Executivo realizava as eleições (com eventual participação do Judiciário) e o Legislativo verificava a lisura do processo; depois dele, a Justiça Eleitoral assumiu as duas funções. Jamais houve a realização das eleições partilhada entre Justiça Eleitoral e governo, ficando o contencioso sob responsabilidade da Justiça Eleitoral.

Para adaptar tal arranjo à bibliografia sobre governança eleitoral, pode-se dizer que o país adotou em 1933 um primeiro modelo de OE, denominado Justiça Eleitoral, que concentrava todas as atividades do rule application e do rule adjudication da eleição política tradicional; e um segundo OE, dividido em duas organizações, válido apenas para a eleição da representação das associações profissionais, no qual as atividades do rule application ficaram com um organismo governamental (o MTIC, que assumiu temporariamente essa atividade atípica para ele) e as do rule adjudication couberam ao Judiciário, por intermédio da Justiça Eleitoral.

As razões para isso, porém, não autorizam supor que tal afastamento da Justiça Eleitoral do pleito classista tenha ocorrido porque o Governo Provisório pretendesse estar livre para promover fraudes nessa eleição e garantir 
uma bancada favorável. Como se buscou demonstrar, a não inclusão da Justiça Eleitoral como $\mathrm{OE}$ naquele pleito não tinha esse objetivo, até porque o Governo Provisório possuía base de apoio em grande parte das associações profissionais. As motivações estão vinculadas ao longo e difícil processo que resultou na decisão do governo de adotar esse novo tipo de representação e de definir um modelo específico, assim como no fortalecimento do modelo de intervenção estatal na organização das classes e na distinção entre os princípios políticos que a sustentam e a distinguem drasticamente da representação popular.

\section{Referências}

AMARAL PEIXOTO, Augusto do (1982). Depoimento, 1975. Rio de Janeiro: Fundação Getúlio Vargas.

A NOITE (1933). "A representação de classes: como está redigido o anteprojeto hoje rejeitado pela mais alta Corte Judiciária Eleitoral do país”. A Noite, 21 fev., p. 3.

ARAÚJO, Ângela (1998). A construção do consentimento: corporativismo e trabalhadores nos anos 30. São Paulo: Scritta.

ASSIS BRASIL, Joaquim Francisco de (1931). Democracia representativa. 4. ed. rev. amp. Rio de Janeiro: Imprensa Oficial.

BARRETO, Alvaro Augusto de Borba (2001). Aspectos institucionais e políticos da representação das associações profissionais, no Brasil, nos anos 1930. Tese (doutorado) em história. Porto Alegre: Pontifícia Universidade Católica do Rio Grande do Sul.

(2002). "O Código Eleitoral de 1932 e a representação das associações profissionais”. História em Revista, n. 8, p. 7-26.

(2004). "Representação das associações profissionais no Brasil: o debate dos anos 1930". Revista de Sociologia e Política. Curitiba, n. 22, p. 119-33.

BORGES, Vavy Pacheco (1992). Tenentismo e revolução brasileira. São Paulo: Brasiliense.

BRASIL (1932). Código Eleitoral (Decreto n. 21.076, de 24 fev. 1932). Disponível em: http://legis.senado.gov.br/legislacao/ListaPublicacoes. action?id=33626. Acesso em: 24 jul. 2014.

(1931). Decreto-lei n. 19.770, de 19 mar. 1931. Disponível em: http:// www.planalto.gov.br/ccivil_03/decreto/Antigos/D19770.htm. Acesso em: 29 set. 2014. 
(1933a). Decreto n. 22.621, de 5 abr. 1933. Disponível em: http:// www2.camara.leg.br/legin/fed/decret/1930-1939/decreto-22621 -5-abril-1933-509274-publicacaooriginal-1-pe.html. Acesso em: 29 set. 2014.

(1933b). Decreto n. 22.653, de 20 abr. 1933. Disponível em: http:// www2.camara.leg.br/legin/fed/decret/1930-1939/decreto-22653-20-abril-1933-518292-publicacaooriginal-1-pe.html. Acesso em: 29 set. 2014.

(1933c). Decreto n. 22.696, de 11 maio 1933. Disponível em: http:// www2.camara.leg.br/legin/fed/decret/1930-1939/decreto-22696-11-maio-1933-517785-publicacaooriginal-1-pe.html. Acesso em: 29 set. 2014.

(1933d). Decreto n. 22.745, de 24 maio 1933. Disponível em: http://www2.camara.leg.br/legin/fed/decret/1930-1939/decreto-22745-24-maio-1933-530101-publicacaooriginal-1-pe.html. Acesso em: 29 set. 2014.

(1933e). Decreto n. 22.940, de 14 jul. 1933. Disponível em: http:// www2.camara.leg.br/legin/fed/decret/1930-1939/decreto-22940-14-julho-1933-516272-publicacaooriginal-1-pe.html. Acesso em: 29 set. 2014.

(1934). Constituição da República dos Estados Unidos do Brasil (16 jul. 1934). Disponível em: http://www.planalto.gov.br/ccivil_03/ constituicao/Constituicao34.htm. Acesso em: 29 set. 2014.

BRASIL (1943). Consolidação das Leis do Trabalho (Decreto-lei 5.452, de 1 maio 1943). Disponível em: http://www.planalto.gov.br/ccivil_03/ decreto-lei/del5452.htm. Acesso em: 29 set. 2014.

CABRAL, João C. da Rocha (2004). Código Eleitoral de 1932. Ed. fac-similar. Brasília: Tribunal Superior Eleitoral.

CADAH, Lucas Queija (2012). Instituições eleitorais e competição política: a criação da Justiça Eleitoral no Brasil. Dissertação (mestrado) em ciência política. São Paulo: Universidade de São Paulo.

CONNIFF, Michael L (1979). "Os tenentes no poder: uma nova perspectiva da Revolução de 30", em FIGUEIREDO, Eurico de Lima (org.). Os militares e a Revolução de 30. Rio de Janeiro: Paz e Terra.

DRUMMOND, José Augusto (1986). O movimento tenentista. Rio de Janeiro: Graal. 
FORJAZ, Maria Cecília Spina (1988). Tenentismo e Forças Armadas na Revolução de 30. Rio de Janeiro: Forense Universitária.

GOMES, Ângela Maria de Castro (1978). "A representação de classes na Constituinte de 1934”. Revista de Ciência Política, v. 21, n. 3, p. 53-116. (org.) (1980). Regionalismo e centralização política: partidos e constituinte nos anos 1930. Rio de Janeiro: Nova Fronteira.

GUERZONI FILHO, Gilberto (2004). “A Justiça Eleitoral no Brasil: a desconfiança como elemento fundamental de nosso sistema eleitoral". Revista de Informação Legislativa. Brasília, a. 41, n. 161, p. 39-45.

HENRIQUES, Affonso (1966). Ascensão e queda de Getúlio Vargas. Rio de Janeiro: Record, 3 vol.

JORNAL DO COMMERCIO (1933). “A situação: foi ontem lido no Tribunal Superior de Justiça Eleitoral o parecer da comissão sobre a representação de classes na Constituinte”. Jornal do Commercio, 18 fev., p. 3.

LEAL, Victor Nunes (1975). Coronelismo, enxada e voto. 2. ed. São Paulo: Alfa Omega.

MARCHETTI, Vitor (2008). “Governança eleitoral: o modelo brasileiro de Justiça Eleitoral”. Dados, v. 51, n. 4, p. 865-93.

MARINHO, Abelardo (1935). Sessão 87, de 6 mar. 1934, da Assembleia Nacional Constituinte, em BRASIL. Anais da Assembleia Nacional Constituinte 1933-1934. Rio de Janeiro: Imprensa Nacional, n. 9, p. 305-41. MORAES FILHO, Evaristo de (1976). "A experiência brasileira da representação classista na Constituição de 1934”. Carta Mensal, v. 22, n. 258, p. 9-38. MORAES, João Quartim de (1994). A esquerda militar no Brasil: da coluna à comuna. São Paulo: Siciliano.

MOZAFFAR, Shaheen \& SCHEDLER, Andreas (2002). “The comparative study of electoral governance: introduction". International Political Science Review, v. 23, n. 1, p. 5-27.

PARROT, Jean-Philippe (1974). La représentation des intérêts dans le mouvement des idées politiques. Paris: Presses Universitaires de France.

PINTO, Emanoel Roberto Girão de Castro (2008). O poder normativo da Justiça Eleitoral. Dissertação (mestrado) em direito. Fortaleza: Universidade Federal do Ceará.

PONTE DE MIRANDA, Francisco Cavalcanti (1936). Comentários à Constituição da República dos Estados Unidos do Brasil de 1934. Rio de Janeiro: Guanabara. 
PRESTES, Anita Leocádia (1999). Tenentismo pós-30: continuidade ou ruptura? Rio de Janeiro: Paz e Terra.

RICCI, Paolo \& ZULINI, Jaqueline Porto (2014). "Partidos, competição política e fraude eleitoral: a tônica das eleições na Primeira República”. Dados, v. 57, n. 4, p. 443-79.

ROSANVALLON, Pierre (1998). Le peuple introuvable: histoire de la représentation democratique em France. Paris: Gallimard.

SERVA, Mário Pinto (1931). A reforma eleitoral. São Paulo: Zenith.

SILVA, Estevão Alves da (2012). As transformações no quadro partidário brasileiro pós-Revolução de 1930. Dissertação (mestrado) em ciência política. São Paulo: Universidade de São Paulo.

SILVA, Hélio (1966). 1931: os tenentes no poder. Rio de Janeiro: Civilização Brasileira.

(1967). 1932: a guerra paulista. Rio de Janeiro: Civilização Brasileira. (1968). 1933: crise do tenentismo. Rio de Janeiro: Civilização Brasileira.

TSJE - TRIBUNAL SUPERIOR DE JUSTIÇA ELEITORAL (1933a). Recurso Eleitoral 13. Boletim Eleitoral, a. 2, n. 122, 12 ago., p. 2.546.

(1933b). Recurso Eleitoral n. 20. Boletim Eleitoral, a. 2, n. 127, 30 ago., p. 2.630-32.

(1933c). Ata da 69a sessão (1 set. 1933). Boletim Eleitoral, a. 2, n. 129, 6 set., p. 2.643.

(1933d). Boletim Eleitoral, a. 2, n. 131, 13 set., p. 2.689-92.

(1933e). Recurso Eleitoral n. 19. Boletim Eleitoral, a. 2, n. 133, 20 set., p. 2.716-21.

VARGAS, Getúlio (1938). A nova política do Brasil. Rio de Janeiro: José Olympio, v. 1 e 3.

\section{Resumo}

O artigo aborda o processo de adoção da representação das associações profissionais na Assembleia Nacional Constituinte brasileira de 1933-1934 e analisa a relação entre o modelo de governança eleitoral que regeu a escolha desses representantes e a Justiça Eleitoral, o organismo eleitoral implantado no mesmo período com vistas a promover a verdade eleitoral na definição da representação popular. Para desenvolver essa tarefa, o texto debruça-se sobre manifestos, entrevistas, matérias jornalísticas e documentos da época, os diplomas legais produzidos no período 1932-1933 (caso do Código Eleitoral, 
dos decretos do Governo Provisório e da Constituição de 1934), bem como sobre a ação da Justiça Eleitoral na resolução do contencioso oriundo de tal processo.

Palavras-chave: Justiça Eleitoral; governança eleitoral; Constituinte; governo Vargas.

\section{Abstract}

The article discusses the adoption process of the representation of professional associations in the Brazilian Constituent Assembly of 1933-34 and examines the relationship between the model of electoral governance that governed the choice of these representatives and the Electoral Justice, the Electoral Office deployed in the same period, in order to promote electoral truth in the definition of popular representation. The development of this work is focused on manifestos, interviews, newspaper articles and documents of the time, the legislation produced in the period 1932-33 (the case of the Electoral Code, the series of decrees of the Provisional Government and the Constitution of 1934), and the Electoral Justice action in the resolution of contentious arising from this process.

Keywords: Electoral Justice, electoral governance, constituent, government Vargas.

Recebido em 10 de novembro de 2014.

Aprovado em 27 de maio de 2015. 